\title{
Open courseware and shared knowledge in higher education
}

\author{
THOMAS E. MALLOY, GARY C. JENSEN, and ALISON REGAN \\ University of Utah, Salt Lake City, Utah \\ and \\ MARY REDDICK \\ California State University, Sacramento, California
}

\begin{abstract}
Most college and university campuses in the United States and much of the developed world today maintain one, two, or several learning management systems (LMSs), which are courseware products that provide students and faculty with Web-based tools to manage course-related applications. Since the mid-1990s, two predominant models of Web courseware management systems have emerged: commercial and noncommercial. Some of the commercial products available today were created in academia as noncommercial but have since become commercially encumbered. Other products remain noncommercial but are struggling to survive in a world of fierce commercial competition. This article argues for an ethics of pedagogy in higher education that would be based on the guiding assumptions of the nonproprietary, peer-to-peer, open-source software movement.
\end{abstract}

\begin{abstract}
The theory behind open source is simple. In the case of an operating system, the source code- the programming instructions underlying the system-is free. Anyone can improve it, change it, exploit it. But those improvements, changes, and exploitations have to be made freely available. Think Zen. The project belongs to no one and to everyone. When a project is opened up, there is rapid and continual improvement. With teams of contributors working in parallel, the results can happen far more speedily and successfully than if the work were being conducted behind closed doors.

—Linus Torvalds, creator of Linux (Torvalds \& Diamond, 2001, p. 226)
\end{abstract}

In the higher education classroom, long-established traditions of academic freedom have encouraged individual instructors to work creatively and independently in accordance with their own pedagogies and institutionalstandards. These traditions are potentially less secure in future on-line courses. In the face of ever-increasing competition and encroachments from both commercial "knowledge vendors" (Arnone, 2001a; Olsen, 2001b) and electronic megauniversities (McCollum, 1998), an academic community of shared content knowledge (Malloy \& Hanley, 2001) and open code software is emerging (J. R. Young, 2001c). One of the primary purposes of open courseware is to help promote cooperation, sharing, and learning among instructors or educational institutions, however large or small, while continuing to respect time-honored individual teaching

Correspondence regarding this article should be addressed to T. E. Malloy, University of Utah, Department of Psychology, Room 502, $380 \mathrm{~S}$. 1530 E., Salt Lake City, UT 84112-0251 (e-mail: malloy@ psych. utah.edu). and learning practices. Of particular importance are open learning management systems (LMSs), which are intended to transfer to the on-line course environment this classroom tradition of free thought and individual expression. At the same time, these LMSs provide members of the academic community with an exciting opportunity to help shape, contribute to, modify, share, and retain ownership of creative endeavors in a course management system.

\section{Commercial Learning Management Systems}

LMSs are the software suites that form the infrastructure for on-line courses. Some of the best-known commercial LMSs include WebCT (http://www.webct.com), eCollege (http://www.ecollege.com/), LearningSpace (http://www.lotus.com), and Blackboard (http://www. blackboard.com/), and there are many more such systems available (Mann, 2000). Components of LMSs, as a minimum, include communication functionality (e.g., e-mail, distribution lists, discussion forums, and live chat) capabilities for delivering content (text, multimedia materials, and simulation programs), and administrative tools (Klobas \& Renzi, 2000, pp. 47-50). LMSs allow instructors to develop and administer on-line courses; it is the instructor who must provide course content. Commercial LMSs are, nevertheless, selling course content that plugs into their LMS interfaces. For example, Blackboard currently advertises 51 content "cartridges" in psychology, and WebCT's Faculty Resource Center boasts of the availability of ePacks containing publisher content that is WebCT-ready.

Although commercial LMSs are lucrative businesses these days, many of these product manufacturers are now engaged in mergers, acquisitions, and agreements with other LMSs, as well as with for-profit on-line subsidiaries 
of nonprofit educational institutions, corporate-university joint ventures, virtual universities, and full-fledged corporate universities. Some nonprofit institutions of higher education, such as Columbia, Cornell, Temple, and UCLA, have already established for-profit subsidiaries or joined with for-profit companies to deliver on-line courses, programs, certificates, and degrees. Newman and Couturier have pointed out, moreover, that the number of corporate universities in the world increased from 400 in 1988 to 2,000 in 2001 (Newman \& Couturier, 2001, pp. 4-6, particularly note 23 ). In some business models, knowledge is plausibly construed as venture capital (Blumenstyk, 2001a). Large private knowledge vendors are buying accredited affiliates (e.g., J. R. Young, 2001b), and in one case, the accreditation process itself has come under commercial influence (Blumenstyk \& McMurtrie, 2000).

A brief account of Blackboard's evolution since it was founded in 1997 is illustrative of these trends. In 1998, Blackboard acquired CourseInfo, an LMS developed at Cornell University. In July 1999, Blackboard, PeopleSoft, and Universal Learning Technology integrated their campus administrative applications and Web-based course software. In June 2000, Eduprise began developing and providing application-hosting and custom service packages for the Blackboard 5 platform, and in May 2001, Blackboard landed Microsoft as a partner in what the two companies called a "preferred relationship." As recently as January 2002 (Arnone, 2001b; Landon, 2002), Blackboard acquired the Prometheus LMS (originally developed by students at George Washington University). Blackboard now claims partnerships with over 50 corporate, digital content, and technology enterprises, supporting the view that the companies most likely to gain prominence in the "educational arms race" are those that can integrate course management systems with other educational applications, thereby providing students and faculty alike with a single log-in portal to all campus administrative and instructional services (Kriger, 2001).

The long-term implications of these developments are uncertain, but the role, value, and meaning of the corporate model of higher education stand in sharp contrast to the role, value, and meaning of the traditional image of institutions of higher learning. The idea of teaching and learning in an academic-industrial complex is at odds with the idea of teaching and learning in an independent campus environment that represents an intellectual and cultural center of towns and cities.

\section{Noncommercial Learning Management Systems}

Web-based course management systems are designed to help improve the quality of teaching and learning by providing on-line services and tools that help the instructor teach students how to think about their subject matter. LMSs are, in short, simply aids to teaching and learning, and it is the instructor's responsibility to teach high-quality, student-centered courses. Commercial LMSs may provide instructors with the tools they need to achieve this goal; however, commercial LMSs do not meet the needs of all instructors (e.g., J. R. Young, 2001a), many instructors are afraid of not having choices among commercial LMSs (Arnone, 2001b), and commercial LMSs reinforce the values of the corporate model of teaching and learning.

Noncommercial LMSs, in contrast, are more flexible, cost effective, and pedagogically promising. Since on-line LMSs are software suites that provide and determine the pedagogical processes by which teaching and learning take place, they also set the constraints for the on-line teaching-learning relationship. When teachers learn to use LMSs, these constraints become part of their mental set about on-line pedagogy; that is, there is no point in thinking about possibilities the tool does not allow. The design of a commercial LMS must be responsive to a good business plan or fail (e.g., J. R. Young, 2000). In contrast, teachers have traditionally designed courses on the basis of an implicit or explicit pedagogy. This natural design tension is familiar. In a classroom course, instructors may choose to use textbooks generated by for-profit companies. Of course, in the classroom, instructors are free to follow their pedagogical intuitions to adjust for the constraints imposed by the text. For an on-line course, however, the LMS, in effect, is the classroom, so the natural adjustments based on a teacher's pedagogy are much more difficult to make; indeed, given the mental presuppositions fostered by learning the LMS design, such adjustments may not come to mind at all. The problem is compounded if the teacher is also purchasing course content, in which case the traditional role of the teacher is vastly reducedpotentially, to that of a course administrator.

The design of a particular LMS determines the creative scope of the on-line teaching-learning context. An open and shared LMS whose pedagogicaldesign evolves freely from the needs of a community of educators, if combined with shared content, can provide the basis for continuing the tradition of academic freedom and individual choice from the classroom to on-line teaching. To this end, noncommercial LMSs, such as the University of Utah's Open Learning Management System (http:www.psych.utah. edu/learn/olms) are joining shared knowledge communities and open-source movements "to foster the adoption and successful use of free and open source solutions in education" (mission statement of the Open Source Schools Web site, http://www.opensourceshcools.org).

The source code of noncommercial LMSs is typically open and available to those who wish to alter, improve, or customize it. For those who do not program, the modules are available as a whole package or as individual modules. Moreover, beyond considerations of software design, the philosophy behind noncommercial LMSs values the principles of shared knowledge in the tradition of intellectual freedom.

\section{Shared Knowledge Communities}

A vigorous teacher- and pedagogy-based shared knowledge movement has emerged, not as a reaction to commercialization, but in its own right. It is motivated by the need of teachers to create on-line courses that are designed 
by individual teachers to fit the needs of individual institutions. This movement has elements both at the LMS infrastructure level and, in the form of plug and play "learning objects" (Olsen, 2001a), at the level of course content and activities. Shared knowledge communities facilitate the creation and extension of instructional content; this content is expressed on line via the design of an LMS software infrastructure.

Open source. The metaphor of the "cathedral and the bazaar," made famous by Eric Raymond's (1999) book of that title, highlights two opposing assumptions guiding software development. The metaphor of developing software in the way that cathedrals are built invokes a slow and tedious process of creating a carefully crafted structure, whereas the metaphor of the bazaar suggests a more spontaneous, open-ended, networked tribe of programmers building collectively upon one another's work (Raymond, 1999). A common value in the bazaar model of shared knowledge communities is open program source code (Perens, 1999; J. R. Young, 2001c). It is generally assumed that when source code is open, the generation of knowledge will evolve relatively rapidly, because an entire community is working on it: "the Open Source movement is an extension of the scientific method... . The open sharing of scientific results facilitates discovery. . . . Similarly, in the Open Source development model, sharing source code facilitates creativity. ... With the source code available, others can step in" (DiBona, Ockman, \& Stone, 1999, pp. 7-8). Open-source code, moreover, "gives customers control over the technologies they use, instead of enabling the vendors to control their customers through restricting access to the code behind the technologies" (B. Young, 1999, p. x). Open-source code provides college and university systems administrators and programmers with the opportunity to help instructors and course designers develop or choose instructional tools and applications that best serve their own pedagogical purposes.

The open-source model, applied to learning objects and LMSs, has three important implications. First, the knowledge base will develop rapidly and spontaneously, as it does in science. Second, developments at one institution that are created by single individuals can be adopted and altered to fit the particular context of teachers at other institutions. Third, the recognition and evolution of an authoritative knowledge community of contributors and users of open-source material provide the basis for peerreviewed criteria for promising practices in teaching excellence.

Shared knowledge sites. Open-source and, more broadly, scientific values about sharing knowledge can be generalized to teaching on line. Course content is available to the teaching community on shared knowledge sites, such as MERLOT (www.merlot.org), the Harvey Project (http://HarveyProject.org/), SMETE (www.smete. org), or the Educational Object Economy (http://www. eoe.org/). Such sites include old media (e.g., text, visual materials, and video streams) but specialize in new media interactivity (see, e.g., Malloy \& Jensen, 2001), such as scientific simulations that engage students in discovery processes. This sharing of learning objects allows teachers to mix materials and activities that they develop on their own with those of other teachers to create course content and to benefit from the resources provided by a structured, peer-reviewed milieu of on-line teachinglearning materials.

The vigor of the shared knowledge community can be seen in the appearance of the Open Knowledge Initiative (OKI; http://web.mit.edu/oki/), which is an effort by a consortium of institutions of higher education to develop a set of standards and an architecture that will enable the construction and dissemination of shared educational applications, including LMSs (J. R. Young, 2001c). It is meant to encourage and enable a collaborative community of academics who are developing on-line teaching software. LMSs and their architecture will play a key role. All participating LMSs will share an architecture and standards that create portability by allowing teachers-if, for instance, they move to an institution that uses a different LMS - to switch course content easily from one LMS to another. The current commercial strategy, if not actually preventing a change of LMS, does not facilitate such changes. A central element of the OKI architecture (http://web.mit.edu/oki/, see Components) will be the use of Java as the implementation language.

\section{Summary}

The sudden appearance of multimedia technology and, even more, on-line technology is requiring a transformation in higher education (Olsen, 2001a). This inevitable transformation can be defaulted to commercial enterprises (Blumenstyk, 2001b) or actively pursued in shared academic knowledge communities (www.educause.edu/) that promote open source code (Carlson, 2001). In the spirit of promoting an ethics of pedagogy, noncommercial LMSs offer open-source software suites that are meant to be a part of the evolving shared software for creating and managing on-line teaching and learning resources. By sharing knowledge in ways that parallel those of science, academics can revitalize the teaching profession through the rapid evolution of pedagogy, technique, and content material in ways that allow peer review of work and due respect for those who contribute to the community of knowledge.

\section{REFERENCES}

Arnone, M. (2001a, October 24). 3 Companies that sell course software say they are raking in money. Chronicle of Higher Education [On line, Daily News]. Retrieved from http://www.chronicle.com.

Arnone, M. (2001b, November 23). Too close for comfort? Some experts fear that ties between Microsoft and Blackboard could diminish colleges' choices. Chronicle of Higher Education [On line, daily news]. Retrieved from http://www.chronicle.com.

Blumensty K, G. (2001a, February 9). Knowledge is a form of "venture capital" for top Columbia administrator. Chronicle of Higher Education, p. A29. 
Blumensty K, G. (2001b, February 20). Professor says colleges should eschew commercial software. Chronicle of Higher Education [On line, daily news]. Retrieved from http://www.chronicle.com.

Blumenstyk, G., \& McMurtrie, B. (2000, October 27). Educators lament a corporate takeover of international accreditor. Chronicle of Higher Education, p. A55.

CARlson, S. (2001, October 3). Hampshire College favors noncommercial Web software open to all. (2001, October 26). Chronicle of Higher Education, p. A35.

DiBona, C., Ockman, S., \& Stone, M. (1999). Introduction. In C. DiBona, S. Ockman, \& M. Stone (Eds.), Open sources: Voices from the open source revolution (pp. 1-17). London: O'Reilly.

KLOBAS, J. \& RenZI, S. (2000). Selecting software and services for Webbased teaching and learning. In A. Aggarwal (Ed.), Web-based teaching and learning: Opportunities and challenges (pp. 43-59). London: Idea Group Publishing.

Kriger, T. J. (2001). A Virtual revolution: Trends in the expansion of distance education. USDLA Journal, 15 [On-line refereed journal]. Retrieved from http://www.usdla.org.

LANDON, B. (2002). Online educational delivery applications: A Web tool for comparative analysis [On line]. Retrieved from http://www. c2t2.ca/landonline.

Malloy, T. E., \& Hanley, G. L. (2001). MERLOT: A faculty-focused Web site of educational resources. Behavior Research Methods, Instruments, \& Computers, 33, 274-276.

Malloy, T. E., \& Jensen, G. C. (2001). Utah Virtual Lab: JAVA interactivity for teaching science and statistics on line. Behavior Research Methods, Instruments, \& Computers, 33, 282-286.

Mann, B. L. (Ed.) (2000). Perspectives in Web course management. Toronto: Canadian Scholars' Press.

McCollum, K. (1998, November 27). Western Governors U. forms consortium with Britain's Open University. Chronicle of Higher Education, p. A23.

Newman, F., \& Couturier, L. (2001, June). The new competitive arena: Market forces invade the academy. The Futures Project, Policy Alternatives [On line]. Retrieved from http://www.futuresproject. org/publications/publications.html.

OLSEN, F. (2001a, January 17). Education must "transform" itself or become irrelevant, Educause Offical says. Chronicle of Higher Education [On line, daily news]. Retrieved from http://www.chronicle.com.

OLSEN, F. (2001b, August 10). Sylvan creates division for online education. Chronicle of Higher Education, p. A49.

Perens, B. (1999). The open source definition. In C. DiBona, S. Ockman, \& M. Stone (Eds.), Open sources: Voices from the open source revolution (pp. 171-188). London: O'Reilly.

RAYMOND, E. (1999). The cathedral and the bazaar: Musings on Linux and Open Source by an accidental revolutionary. Sebastopol, CA: O'Reilly.

Torvalds, L., \& DiAmond, D. (2001). Just for fun: The story of an accidental revolutionary. New York: HarperCollins.

Young, B. (1999). Foreword. In The Cathedral and the bazaar: Musings on Linux and Open Source by an accidental revolutionary (p. x). Sebastopol, CA: O'Reilly.

YounG, J. R. (2000, June 30). Veteran of California Virtual U. blames a flawed business plan for its demise. Chronicle of Higher Education, p. A44.

Young, J. R. (2001a, November 2). Frustrated Blackboard customers form independent users' group. Chronicle of Higher Education [On line, daily news]. Available: http://www.chronicle.com.

Young, J. R. (2001b, February 16). Sylvan buys major stake in Walden University. Chronicle of Higher Education, p. A45.

Young, J. R. (2001c, May 4). Universities begin creating a free, "open source" course-management system. Chronicle of Higher Education, p. A36.

(Manuscript received November 8, 2001; revision accepted for publication February 24, 2002.) 